\title{
RECENT DeVELOPMENTS IN INDIANA CRIMINAL LAW AND PROCEDURE
}

\author{
JOEL M. SCHUMM*
}

Indiana's appellate courts confronted a variety of significant issues during the survey period October 1, 2016, to September 30, 2017. Justice Rucker's nearly two decades of service on the Indiana Supreme Court concluded in May, and Justice Goff took the bench in July. ${ }^{1}$ With that appointment, the court has been transformed from the five justices who served together from 1999-2010 (Shepard, Dickson, Sullivan, Boehm, and Rucker), to five justices with an average of less than four years of experience (Rush, David, Massa, Slaughter, and Goff). ${ }^{2}$ As explored below, the new court has increasingly used per curiam opinions and otherwise generally resolved cases on narrow grounds.

This Article focuses on opinions from the Indiana Supreme Court and many of the significant opinions from the Indiana Court of Appeals, on a wide range of issues that affect cases from their beginning to end.

\section{SPEEDY TRIAL}

Hoskins v. State ${ }^{3}$ provides several useful reminders of the State's duty to bring a criminal defendant to trial within the time periods of Criminal Rule 4 . Although the clock does not run during periods of delay caused by the defendant, the court found the State to blame for most of the delays in reversing convictions for marijuana offenses against two defendants. ${ }^{4}$

First, the court of appeals reiterated that the clock starts running when charges are filed (or upon arrest, if that occurs later) - and not the date the defendant retains counsel. ${ }^{5}$ The court distinguished cases where the defendant had taken actions that caused a delay, observing in this case, the defendant had not changed counsel, waited "an unreasonable amount of time to retain counsel, or in any way delay[ed] the setting of the trial with respect to retention of counsel."

Moreover, the court of appeals refused to charge the defendant with the delay caused by the State's request for a continuance after the defendant requested the return of three cell phones seized during his arrest. ${ }^{7}$ Because the phones had been in the State's possession for eight months before the defendant requested their return, the court characterized the "extraordinarily belated search" a "strategic"

* Clinical Professor of Law, Indiana University Robert H. McKinney School of Law. B.A., 1992, Ohio Wesleyan University. M.A., 1994, University of Cincinnati. J.D., 1998, Indiana University School of Law-Indianapolis.

1. Supreme Court Justices, https://mycourts.in.gov/JR/Default.aspx [perma.cc/9ZSU-L28C] (last visited Mar. 28, 2018).

2. $I d$.

3. 83 N.E.3d 124 (Ind. Ct. App. 2017).

4. Id. at $127-30$.

5. Id. at 127 .

6. $I d$.

7. Id. at 128-29. 
decision for which the State was responsible. ${ }^{8}$ Similarly, the court held the State responsible for the delay caused in the other defendant's case by the State waiting "until the last minute to listen to jail calls" that led it to seek search warrants for the phones because it would be "unfair" to charge the defendant with the delay resulting "from the way in which the State conducted its case."

\section{CORPUS DELICTI}

Corpus delicti, a fancy word most lawyers may remember hearing in law school, seldom plays a leading role in appellate decisions. This year provides a not-easily-forgotten exception in a bestiality case. In Shinnock v. State, ${ }^{10}$ the Indiana Supreme Court began by citing decades-old authority to provide an explanation of general principles of the doctrine:

a person may not be convicted of a crime based solely on a nonjudicial confession of guilt. Rather, independent proof of the corpus delicti is required before the defendant may be convicted upon a nonjudicial confession. Proof of the corpus delicti means "proof that the specific crime charged has actually been committed by someone." Thus, admission of a confession requires some independent evidence of commission of the crime charged. The independent evidence need not prove that a crime was committed beyond a reasonable doubt, but merely provide an inference that the crime charged was committed. This inference may be created by circumstantial evidence. ${ }^{11}$

As the court explained in Shinnock, "[t]he corpus delicti evidence required to have a confession admitted is not the same as the corpus delicti evidence required to sustain a conviction." 12 The court of appeals had held "the State was required to prove penetration of the dog's sex organ by a male sex organ before it could admit Shinnock's statement" at trial. ${ }^{13}$ The Indiana Supreme Court disagreed, detailing the independent circumstantial evidence that provided an inference that the defendant had committed bestiality, which made the confession admissible. ${ }^{14}$ The State was not required to prove all the elements of the offense before introducing the confession. ${ }^{15}$

8. Id. at 128 .

9. Id. at 130 .

10. 76 N.E.3d 841 (Ind. 2017).

11. Id. at 843 (internal citations omitted).

12. Id. at 844 .

13. Id. at 842 .

14. Specifically, the dog-victim was not at the door to greet her owner "when he arrived home like she usually did. Instead, she was found trapped in Shinnock's bedroom with him. He was in his underwear and had an erection. The floor was covered in dog feces, which was unusual. When [the owner] opened the door to Shinnock's room, [the dog] ran to hide under the couch." Id. at 844 .

15. Id. 


\section{PROCEDURAl Rights: SELF-REPRESENTATION, PleA AgREEMENTS, CLOSING ARGUMENTS}

The appellate courts addressed important procedural rights of defendants involving self-representation, guilty pleas, contempt, and closing arguments.

\section{A. Failure to Warn Defendant of Dangers of Self-Representation}

In Hart v. State, ${ }^{16}$ the court of appeals reiterated that defendants cannot knowingly and intelligently waive their right to counsel without the trial court advising them of "the dangers and disadvantages of self-representation." ${ }^{17}$ There, the defendant charged with invasion of privacy told the trial court he did not want court-appointed counsel and failed to retain counsel for months before trial, ultimately requesting a continuance one week before his scheduled trial. ${ }^{18}$ The continuance was denied, and Hart represented himself at a three-day jury trial during which "the trial court never questioned his lack of representation." 19 In a footnote, the court reiterated that defendants may forfeit the right to counsel through abusive or "extremely dilatory" conduct, which does not require an advisement of the dangers and disadvantages of self-representation but did not apply to Hart's conduct. ${ }^{20}$

\section{B. Defendants Cannot Claim Innocence and Plead Guilty}

Indiana courts have long required a defendant's admission of guilt before a trial court may accept a guilty plea. "[A] plea of guilty tendered by one who in the same breath protests his innocence, or declares he actually does not know whether or not he is guilty, is no plea at all. Certainly it is not a sufficient plea upon which to base a judgment of conviction." 21 And, more recently, "a judge may not accept a plea of guilty when the defendant both pleads guilty and maintains his innocence at the same time. To accept such a plea constitutes reversible error." 22

The Indiana Supreme Court reaffirmed those principles in Ellis v. State, ${ }^{23}$ a case where the defendant pleaded guilty to two counts of attempted murder and two counts of attempted robbery. ${ }^{24}$ Although the State's theory was that Ellis was an accomplice and not a principal, he maintained his innocence at the plea hearing, stating he "didn't do nothing . . . didn't cut nobody . . . did not rob

16. 79 N.E.3d 936 (Ind. Ct. App. 2017).

17. Id. at 941 .

18. Id. at 938-39.

19. Id. at 939 .

20. Id. at 941 n.1.

21. Harshman v. State, 115 N.E.2d 501, 502 (Ind. 1953).

22. Ross v. State, 456 N.E.2d 420, 423 (Ind. 1983).

23. 67 N.E.3d 643 (Ind. 2017).

24. Id at 645 . 
nobody." ${ }^{25}$ He testified he tried to stop the attack by telling the co-defendant "don't do it." 26 Even though Ellis "contributed to his own demise by pleading guilty," the supreme court held the trial court should not have accepted the plea because it was "accompanied with a protestation of innocence and unaccompanied by evidence showing a factual basis for guilt." 27

\section{State Cannot Withdraw from Plea Agreement Because It Failed to Notify Victim}

Article 1, Section 13 of the Indiana Constitution provides rights to crime victims but expressly limits those rights if they "infringe upon the constitutional rights of the accused. ${ }^{, 28}$ In Messersmith $v$. State, ${ }^{29}$ the trial court accepted a plea agreement from the State and Defendant, but later granted the State's request to withdraw from the agreement because it had entered the agreement without notifying the victim. ${ }^{30}$ Trial courts sometimes have discretion to revoke plea agreements, such as when defendants claim innocence at sentencing or breach the terms of the plea agreement. ${ }^{31}$ But "due process requires that the government uphold its side of the bargain," and thus the trial court abused its discretion by allowing the State to void the agreement based on its failure to notify the victim. ${ }^{32}$

\section{Strict Compliance Not Required When Sufficient Notice Was Given}

Although grounded in a civil contempt statute, Reynolds $v$. Reynolds ${ }^{33}$ has potential relevance in the criminal realm. There, the Indiana Supreme Court held that strict compliance with the statute can be excused if the party in contempt has been sufficiently notified of their contempt. ${ }^{34}$ Justice Slaughter dissented because the plain language of the statute Indiana Code section 34-47-3-5(a) "required the trial court to issue a rule to show cause detailing the factual basis for Father's alleged contempt," which did not occur. ${ }^{35}$

\section{E. Denial of Right to Make Closing Argument in Bench Trial}

In Nickels v. State, ${ }^{36}$ the trial court erred in preventing defense counsel from

25. Id. at 648 .

26. Id.

27. Id. at 651 (quoting Boles v. State, 303 N.E. 2d 645, 654 (Ind. 1973)).

28. IND. CONST. art. $1, \S 13$.

29. 70 N.E.3d 861 (Ind. Ct. App. 2017).

30. Id. at 863 .

31. Id. at 864-65.

32. Id. at 865 (citing Santobello v. New York, 404 U.S. 257, 262 (1971)).

33. 64 N.E.3d 829 (Ind. 2016).

34. Id. at 833 .

35. Id. at 836 .

36. 81 N.E.3d 1092 (Ind. Ct. App. 2017). 
making a final argument during a bench trial. ${ }^{37}$ At the close of evidence in a domestic battery case, the trial court allowed the State the opportunity to make an argument, which was interrupted to announce it was finding for the State - only then, only after it had already announced its intention to find against her, was the defendant asked for an argument. ${ }^{38}$ Defense counsel simply responded that the State failed to meet its burden of proof, and the trial court immediately asked for sentencing recommendations. ${ }^{39}$

An opportunity to make a closing argument is a basic element of the criminal process; "it clarifies and sharpens the issues, gives the defense one last chance to persuade the trier of fact there may be reasonable doubt of the defendant's guilt, and, in a bench trial, aids the judge's decision-making by providing opposing viewpoints." ${ }^{40}$ Concluding that the trial court's "invitation' for defense counsel to give closing argument was at best an empty formality," the court of appeals reversed the convictions and remanded for a new trial. ${ }^{41}$

\section{APPELLATE REVIEW OF VIDEO EVIDENCE}

As cameras proliferate - on smartphones, as police body cameras, and for security, to name a few - courts must grapple with a variety of issues with video evidence. As discussed in a past survey article, ${ }^{42}$ the Indiana Supreme Court held in 2013 that it "consider[s] video evidence admitted in the trial court to be a necessary part of the record on appeal, just like any other type of evidence." "A3 "And just like any other type of evidence, video is subject to conflicting interpretations." Although the deputy's testimony of driving near a fog line conflicted to some extent with the police vehicle video, the supreme court emphasized the importance of the police officer's "experience and expertise," which "led the trial judge to weigh [the officer's] testimony more heavily than the video evidence" and "decline[ed] Robinson's invitation to substitute [Indiana Supreme Court's] own judgment for that of the trial court and rebalance the scales in [Robinson's] favor., ${ }^{45}$

\section{Id. at 1093.}

38. Id. at 1095 .

39. Id. at 1094-95.

40. Id. at 1096 (citing Herring v. New York, 422 U.S. 853, 864-65 (1975)).

41. Id. at $1095,1097$.

42. Joel M. Schumm, Recent Developments in Indiana Criminal Law and Procedure, 48 IND. L. REV. 1241, 1247-48 (2015).

43. Robinson v. State, 5 N.E.3d 362, 366 (Ind. 2014).

44. Id.

45. Id. at 367. The Indiana Supreme Court took a somewhat different approach a year before Robinson, though, in a case where a school liaison officer believed a student had forcibly resisted arrest. See generally K.W. v. State, 984 N.E.2d 610 (Ind. 2013). In reversing the juvenile court's true finding, the supreme court mentioned both the officer's testimony and video of the incident, seemingly placing more weight on the video. "The surveillance video further confirms Sergeant Smith's restrained and cautious characterization of K.W.'s conduct. It shows K.W. turning and 
Love v. State, ${ }^{46}$ decided in 2017 , cites and narrowly expands Robinson by supplementing the "standard of review for video evidence to add a narrow failsafe." ${ }^{\prime 47}$ Significant deference is still afforded to fact-finder "until there is a reason such deference is not appropriate." ${ }^{\text {" }} 8$ Reversal is warranted only when "the video evidence indisputably contradicts the trial court's findings," which means that "no reasonable person could view the video and conclude otherwise." ${ }^{49}$ The court provided specific guidance for assessing whether video is indisputable, which includes "the video quality including whether the video is grainy or otherwise obscured, the lighting, the angle, the audio and whether the video is a complete depiction of the events at issue, among other things." ${ }^{50}$

Indiana's deferential approach appears to place it among the majority of courts that have addressed the issue. ${ }^{51}$

\section{CRIME OR NOT A CRIME?}

As suggested in previous survey articles, challenges to the sufficiency of evidence in a criminal case are often raised and frequently fail. This section begins with cases where convictions were upheld based on finding of sufficient evidence and ends with cases in which the appellate courts reversed for lack of evidence.

\section{A. Not a Crime}

1. Ohio Burglary Statute "Substantially Similar" to Indiana's for SVF.- In State v. Hancock, ${ }^{52}$ the Indiana Supreme Court found the Ohio offense of second degree burglary was substantially similar to Indiana's Level 4 burglary; therefore, the Ohio burglary conviction made the defendant eligible to be a serious violent felon. ${ }^{53}$ Although the phrase "any criminal offense" in the Ohio statute appears to make it broader than Indiana's statute, Ohio courts have interpreted their statute to apply to a person who intends to commit theft, rendering the statute substantially similar to Indiana's statute. ${ }^{54}$

Justice David, dissented, opining that the Ohio statute is broader than the

taking a step away from Sergeant Smith while his arm was still in the officer's grasp ...." Id. at 613 n.1.

46. 73 N.E.3d 693 (Ind. 2017).

47. Id. at 695 .

48. Id. at 699 .

49. Id.

50. Id.

51. See generally Kevin W. Bufford, Appellate Review - the Split on the Proper Standard of Review for Police Video Evidence - Scott v. Harris, 550 U.S. 372 (2007), 39 AM. J. TRIAL Advoc. 447, 449-54 (2015).

52. 65 N.E.3d 585 (Ind. 2016).

53. $I d$. at 592-93.

54. Id. at 589-90. 
Indiana statute - by the words "any criminal offense." 55 Thus, that any misdemeanor offense might suffice for burglary in Ohio is more than a mere "academic possibility," such as a person who breaks into a home and commits a non-theft misdemeanor, like stalking. ${ }^{56}$

Finally and more broadly, the court observed that trial "[c]ourts may of course perform their own research," but it "is unrealistic to expect our increasingly busy trial courts to undertake such efforts." ${ }^{, 7}$ Thus, "[t]he onus of presenting another jurisdiction's law lies properly with the party relying on that law." 58

2. Battery Conviction Affirmed Over Claim of Parental Discipline Privilege.-Indiana's robust parental discipline privilege may offer a defense to the battery of children based on a weighing of factors adopted the Indiana Supreme Court in Willis v. State in 2008:

(a) whether the actor is a parent;

(b) the age, sex, and physical and mental condition of the child;

(c) the nature of his offense and his apparent motive;

(d) the influence of his example upon other children of the same family

or group;

(e) whether the force or confinement is reasonably necessary and appropriate to compel obedience to a proper command;

(f) whether it is disproportionate to the offense, unnecessarily degrading, or likely to cause serious or permanent harm. ${ }^{59}$

In Carter v. State, ${ }^{60}$ the defendant punished his fourteen-year-old daughter for dishonesty and "offer[ing] herself" to boys through pictures posted on social media. ${ }^{61}$ The majority affirmed the battery conviction, emphasizing the trial court's role in weighing evidence and assessing credibility related to parental discipline. ${ }^{62}$ Some form of punishment was warranted "to control and deter M.C.'s escalating defiance and dangerous behavior," and the majority declined to override the trial court's balancing of the Willis factors, which found "at least fourteen strikes with a belt which resulted in significant bruising and lasting pain" excessive. ${ }^{63}$

55. Id. at 593.

56. Id. at 593 .

57. Id. at 593 n.8.

58. Id.

59. 888 N.E.2d 177, 182 (Ind. 2008) (quoting Restatement (SECOND) OF TorTs, § 150 (1965)); see generally IND. CODE § 35-41-3-1 (2017) (“A person is justified in engaging in conduct otherwise prohibited if he has legal authority to do so.").

60. 67 N.E.3d 1041 (Ind. Ct. App. 2016), trans. denied, 80 N.E.3d 180 (Ind. 2017).

61. Id. at 1043 .

62. Id. at 1048 .

63. Id. 
Judge Crone wrote a separate opinion "reluctantly" concurring. ${ }^{64} \mathrm{He}$ expressed concern about the dramatically different attitudes within generations and cultures regarding corporal punishment of children and reiterated the majority's concerns that the "vague reasonableness standard" from Willis made it difficult for prosecutors and courts to determine when a "law-abiding citizen" becomes a "criminal." ${ }^{65} \mathrm{He}$ asked rhetorically: "If the purpose of the criminal law is to put a person on notice of what conduct is proscribed and what is permitted, then how can one's guilt or innocence depend upon how someone else disciplines his or her children when there is no consensus about what is appropriate?" 66

3. Criminal Recklessness for Firing "into" a Dwelling.-The base criminal recklessness offense is a Class B misdemeanor but may be elevated to a Level 5 felony when the reckless act "is committed by shooting a firearm into an inhabited dwelling or other building or place where people are likely to gather." ${ }^{97}$

In Williams v. State ${ }^{68}$ the defendant told police he fired a gun at a raccoon in a residential neighborhood. ${ }^{69}$ The bullet "entered the siding of one house, passed through the corner exiting that house, ricocheted, and lodged in the siding of the second story of another house." "70 Applying a "plain reading" of the term "into," the court of appeals found that the siding of a house "delineates the boundary of the dwelling," and "[t]he extent to which a bullet penetrates the dwelling is a matter of degree, but is 'into' the dwelling, nonetheless." statute further supported "policy considerations" by "protecting from the risk of injury due to gunfire those who might be present in an inhabited dwelling." 72

4. Burglary Conviction Affirmed for House Squatter.-In Brown v. State, ${ }^{73}$ the court of appeals found sufficient evidence of burglary when the defendant occupied a home being prepared for sale after foreclosure. ${ }^{74}$ The court found ample evidence of his intent to commit a felony because the defendant "had no intention of vacating the [p]roperty" when he "broke into the house with the intent to use the house as his personal residence" by moving in his personal belongings, changing the locks, and posting no-trespassing signs. ${ }^{75}$ Similarly, the defendant could not rely on the doctrine of adverse possession because his possession was a mere two months, much less than the required ten years, and he had no claim of title for the property. ${ }^{76}$

64. Id. at 1049.

65. Id.

66. Id.

67. IND. CODE $§ 35-42-2-2(\mathrm{~b})(2)(\mathrm{A})$ (2017) (emphasis added).

68. 64 N.E.3d 226 (Ind. Ct. App. 2016).

69. Id. at 228 .

70. Id. at 230 .

71. Id.

72. Id.

73. 64 N.E.3d 1219 (Ind. Ct. App. 2016), trans. denied, 88 N.E.3d 1078 (Ind. 2017).

74. Id. at 1232 .

75. Id. at 1231 .

76. Id. at 1232 . 
5. Sufficient Evidence of Auto Theft.-In Thacker v. State, ${ }^{77}$ the defendant argued that his possession of a vehicle six days after it was stolen was insufficient to prove auto theft. ${ }^{78}$ Although possession of "recently stolen" property may be sufficient to support a theft conviction, additional evidence is required when the theft is not recent, such as case involving possession two days after the theft. ${ }^{79}$

In Thacker, the court of appeals found ample additional evidence to support the inference that the defendant knew the vehicle he possessed had been stolen. The State offered evidence of pry marks around the passenger window, which had been "busted out," in addition to damage to a door and a "ripped off" gas cap. ${ }^{80}$ In addition to the damage, the defendant and his companion attempted to flee when encountered by police. ${ }^{81}$

6. Possession of Child Pornography Includes Viewing Images on a Computer.-A defendant commits possession of child pornography if he "intentionally pointed a web browser to certain websites containing images of child pornography, and intentionally viewed the pornographic images therein," the court of appeals held in Eckrich v. State. ${ }^{82}$ That the defendant did not know of the caching process for storing images on his computer was immaterial; he controlled when the images would appear and for how long - "free to use the image as he desired" while on his screen. ${ }^{83}$ The case was originally issued as a memorandum decision but later published at the State's request. ${ }^{84}$

7. Pavement can be a Deadly Weapon.-In Burgh v. State, ${ }^{85}$ the court of appeals held as a matter of first impression that "the paved surface of a parking lot" used in a manner "readily capable of causing serious bodily injury" can be a "deadly weapon," thus elevating the battery charge to a Level 5 felony. ${ }^{86}$ The defendant used the pavement as a blunt object into which he smashed the victim's skull, similar to the use of a rock, which was previously held to fall within the statute. ${ }^{87}$ The deadly weapon definition is not limited to moveable objects but can extend to stationary objects if used in a manner readily capable of causing serious injury. ${ }^{88}$

8. Violation of Protective Order for Communication Beyond Discussing Parenting Time.-Although protective orders generally prohibit any contact, trial courts may include provisions to allow limited contact, such as discussions of

77. 62 N.E.3d 1250 (Ind. Ct. App. 2016).

78. Id. at 1252 .

79. Id.

80. Id.

81. Id.

82. 73 N.E.3d 744, 746 (Ind. Ct. App.), trans. denied, 88 N.E.3d 1079 (Ind. 2017).

83. Id. at $746-47$.

84. Id. at 744 .

85. 79 N.E.3d 955 (Ind. Ct. App. 2017).

86. Id. at $956-58$.

87. Id. at 957.

88. Id. at 958 . 
parenting time issues. In Jordan v. State ${ }^{89}$ however, the defendant exceeded the scope of permissible communication when he "used aggressive words, including ad hominem attacks" when communicating to the protected person. ${ }^{90}$

The court also rejected Jordan's argument of insufficient notice of the terms of the protective order, which were provided orally by law enforcement before a written copy was mailed to him. ${ }^{91}$ Reiterating that oral notice may be sufficient when it includes "'adequate indication of the order's terms," "92 the appellate court recited Jordan's own testimony that the officer told him he could not contact the protected person, "which is exactly what he did when he left her the voicemail message. ${ }^{\prime 93}$

9. Neglect of Dependent Conviction Upheld Despite Defendant's IQ of SixtySeven.-Four months after his birth, an extremely malnourished baby boy who weighed just over six pounds and had bed sores on his back died at home, in Pierson v. State. ${ }^{94}$ Charged with murder and neglect of a dependent, his father pursued a defense of insanity based on his intellectual disability of an IQ consistently around sixty-seven. ${ }^{95} \mathrm{~A}$ jury convicted him of neglect of a dependent, which was affirmed on appeal. ${ }^{96}$ The court of appeals pointed to expert testimony that the defendant "would be capable of basic life tasks, like feeding a child," and noted he had taken basic care of three older children, "including changing them, playing with them, and feeding them."

Whether the defendant knowingly and voluntarily neglected his child was "an extremely difficult and fact-sensitive inquiry, which our justice system reserves for a jury." 98 Although the case was a "tragedy" that resulted in sending a man "to prison for failing to do what he may be barely capable of doing," the court of appeals emphasized the standard of review forbids an appellate court from "disturbing the determination of the jury" when some of the conflicting evidence suggested he "was capable of understanding the harm that the failure to feed [his son] was inflicting." 99

\section{B. Cases Reversing Convictions}

1. Resisting by Flight.-Although Indiana's appellate courts frequently address challenges to the sufficiency of evidence for "forcibly" resisting law

89. 77 N.E.3d 1271 (Ind. Ct. App. 2017).

90. Id. at 1273 .

91. Id. at 1274 .

92. Id (quoting Tharp v. State, 942 N.E.2d 814, 818 (Ind. 2011)).

93. $I d$.

94. 73 N.E.3d 737, 738-39 (Ind. Ct. App.), trans. denied, 88 N.E.3d 1079 (Ind. 2017).

95. Id. at 739 .

96. Id. at $740-44$.

97. Id. at 741 .

98. Id.

99. Id. 
enforcement, ${ }^{100}$ they are occasionally presented with challenges to convictions for resisting by "flee[ing] from a law enforcement officer after the officer has, by visible or audible means . . . identified himself or herself and ordered the person to stop." ${ }^{101}$ Flight in this context requires "a knowing attempt to escape law enforcement when the defendant is aware that a law enforcement officer has ordered him to stop or remain in place once there," as explained last year in Cowans v. State. ${ }^{102}$

In West v. State, ${ }^{103}$ a grandmother walked toward a bedroom to protect her two-year-old grandson as police raided her home. ${ }^{104}$ Relying on Cowans and the importance of the defendant's intent, the court of appeals reversed, finding no evidence the defendant "intended to flee, escape, or even unnecessarily prolong her exit from the home." 105 Nor was there any evidence she was ordered by police to stop "in the twenty seconds of chaos during which West is alleged to have fled from police by walking toward her grandson's bedroom"; rather, officers had "instructed everyone inside to exit."

2. Handgun Location Is an Essential Element of Carrying Without a License.- Interpreting the 2003 version of the statute, in Webster v. State ${ }^{107}$ the court of appeals reiterated whether a handgun is on a person's own property or fixed place of business is an essential element of the offense - not an affirmative defense or exception to the statute. ${ }^{108}$ The State offered no evidence that the address where an unlicensed handgun was found was not the defendant's dwelling, property, or fixed place of business. ${ }^{109}$ Therefore, the trial court "clearly erred" when it denied a motion for involuntary dismissal. ${ }^{110}$ Since 2003, the language of the statute has changed, but the same principle continues to apply: the State has the burden to prove the defendant carried a handgun in a place "other than" one permitted under the statute. ${ }^{111}$

3. Handgun Obtained During Burglary Cannot Enhance Charge.-The base burglary offense is a Level 5 felony but may be enhanced to a Level 2 felony if "committed while armed with a deadly weapon." 112 In State v. McHenry, a

100. See, e.g., Walker v. State, 998 N.E.2d 724, 727 (Ind. 2013) (discussing several reversed cases).

101. IND. CoDE § 35-44.1-3-1(a)(3) (2017).

102. 53 N.E.3d 540, 545 (Ind. Ct. App. 2016) (quoting Wellman v. State, 703 N.E.2d 1061, 1063 (Ind. Ct. App. 1998)).

103. 85 N.E.3d 608 (Ind. Ct. App. 2017).

104. Id. at 611 .

105. Id.

106. Id.

107. 64 N.E.3d 919 (Ind. Ct. App. 2016).

108. Id. at 921-22.

109. Id.

110. Id.

111. Webster, 64 N.E.3d at 922; compare IND. CODE $§ 35-47-2-1$ (a) (2017), with IND. CODE $\S 35-47-2-1$ (a) (2003).

112. IND. CoDE $\S 35-43-2-1(3)(A)(2017)$. 
defendant who stole a gun during a burglary was charged with a Level 2 offense. ${ }^{113}$

The court of appeals upheld the trial court's dismissal of the Level 2 offense, explaining that "a person is not armed merely by virtue of possessing a weapon." 114 Specifically, the defendant had not "handled the gun in a manner indicative of using it or involving it in the crime in any way" but instead "her sole objective appears to have been the theft of items that could be traded for drugs." 115 Although many other jurisdictions have allowed enhanced charges when a defendant who enters a dwelling unarmed acquires a weapon during a burglary, the court of appeals concluded, based on the plain language of the statute, "the degree of the offense of burglary does not change as a result of the nature of the items stolen." 116

\section{REMEDY FOR WRONG MENS REA AT BENCH TRIAL}

The judge presiding over the bench trial in Miller $v$. State ${ }^{117}$ found the defendant guilty of attempted murder because he "knowingly or intentionally" attempted to commit murder. ${ }^{118}$ In a per curiam opinion on transfer, the Indiana Supreme Court agreed with the court of appeals that the judge applied the wrong mens rea standard in finding the defendant guilty of attempted murder. ${ }^{119}$ However, the supreme court remanded not for a new trial, as the court of appeals had, but simply for the same judge to reconsider the evidence under the correct mens rea standard, which required the State to prove the defendant had the specific intent to kill the victim. ${ }^{120}$ Justice Slaughter dissented regarding the remedy, believing that Miller should receive a new trial. ${ }^{121}$ Although unusually short, the opinion appears to address an issue of first impression, and the outcome was somewhat surprising for at least a few reasons. ${ }^{122}$

First, the court has long and consistently set a high bar of expectations for our trial courts. When mistakes are made, remedies proportionate to the error and its effect on the ultimate fairness of the proceeding are the norm. For example, the court recently discussed and applied "the well-settled due process right to an impartial court as necessary to a fair proceeding," noting that cases have primarily

113. State v. McHenry, 74 N.E.3d 577, 579 (Ind. Ct. App.), trans. denied, 88 N.E.3d 1079 (Ind. 2017).

114. Id. at 581 .

115. Id.

116. $I d$.

117. 77 N.E.3d 1196 (Ind. 2017).

118. Id. at 1197.

119. Id.

120. Id.

121. Id. at 1198 (Slaughter, J., dissenting).

122. This author served as counsel for the Marion County Public Defender Agency, which filed an amicus brief in support of Miller's petition for rehearing. Much of this section is derived from that brief. 
focused on judicial comments in front of jurors while making clear that inappropriate comments at a bench trial are just as problematic and damaging. ${ }^{123}$ Unlike in that case, the judge in Miller did not use coarse language or insult parties by name-calling, but concern of similar magnitude is warranted when a trial court applies an incorrect legal standard to the ultimate determination of guilt. ${ }^{124}$

The gravity of the error, reciting and applying the incorrect legal standard when rendering a verdict, is similar to a trial court's post-verdict comment on evidence that contradicts and undermines its verdict, which has warranted vacating a conviction on sufficiency grounds. ${ }^{125}$ The error is much deeper than the trial court making one erroneous ruling in the course of a trial, ${ }^{126}$ or the trial court relying on an improper consideration and a number of proper ones during sentencing. ${ }^{127}$ In contrast, the recitation and application of the wrong legal standard in a bench trial - originating in the State's charging information - is a cause for greater concern because of the potentially serious consequences.

Miller may also change the considerations of counsel in advising clients about whether to waive jury in a felony case or request a jury in a misdemeanor case. ${ }^{128}$ Before Miller, defense counsel would sometimes recommend clients consider a bench trial in cases involving complicated legal issues, which judges may be better equipped to sort through than jurors, and cases with especially unpleasant facts that judges may be better positioned to look beyond in applying the law to reach a verdict. When defendants choose a bench trial, they often express their belief that the judge will be fairer-and may anticipate an

123. In re J.K., 30 N.E.3d 695, 699 (Ind. 2015).

124. See, e.g., Galloway v. State, 938 N.E.2d 699, 703 (Ind. 2010) (reversing a guilty but mentally ill verdict in a murder case on sufficiency grounds in light of unanimous expert opinion of insanity, while also addressing the trial court's improper remarks, including those made at sentencing); Hollinsworth v. State, 928 N.E.2d 201, 201-02 (Ind. 2010) (granting transfer to remand a misdemeanor case for a new trial based on the trial court's comments showing a lack of impartiality).

125. Kribs v. State, 917 N.E.2d 1249, 1250 (Ind. Ct. App. 2009) ("Following a bench trial that resulted in Kribs's conviction, the trial court observed that Kribs was unaware that he had a weapon in his possession at the time of the incident in question. Given this finding, which we may not and will not second guess, we are compelled to reverse for insufficient evidence.”).

126. See generally Konopasek v. State, 946 N.E.2d 23 (Ind. 2011) (addressing the judicialtemperance presumption).

127. Anglemyer v. State, 868 N.E.2d 482, 491 (Ind.), clarified on reh'g, 875 N.E.2d 218 (Ind. 2007) (explaining that "remand for resentencing may be the appropriate remedy if we cannot say with confidence that the trial court would have imposed the same sentence had it properly considered reasons that enjoy support in the record.").

128. The Rules of Professional Conduct require counsel to "reasonably consult with the client about the means by which the client's objectives are to be accomplished." IND. PrOF'L CONDUCT R. 1.4(a)(2). A later part of that rule requires lawyers "explain a matter to the extent reasonably necessary to permit the client to make informed decisions regarding the representation." IND. PROF'L CONDUCT R. 1.4(b). 
explanation for a decision instead of the jury's reading of a preprinted verdict form. If the judge does not know the law (or recites and applies the wrong law) defendants do not get what they bargained for in waiving jury.

Finally, confidence in the system is diminished when those sitting in a courtroom - lawyers, the public, and the press - are left to question the depth and breadth of justice in Indiana courtrooms. Perception matters, and a remand for new findings in the face of a significant, deep-seated misstatement of the law creates an undesirable perception for litigants and the public.

The Indiana Supreme Court has long emphasized the essential, personal role of a defendant in deciding whether to proceed to a jury or bench trial, the latter of which requires a personal waiver made knowingly and intelligently in felony cases. ${ }^{129}$ When defendants elect a bench trial, they necessarily expect judges to follow the law. Indeed, judges - with years of legal education, often decades of experience, and heightened continuing education requirements - are legal experts from whom counsel, litigants, and the public should expect more than they do of jurors, laypeople who generally lack any legal training and may be thrust into a legal dispute once or twice in their lifetimes.

Although initially decided as a 3-1 opinion, Chief Justice Rush joined Justice Slaughter in voting to grant rehearing. ${ }^{130}$ Thus, considering the division among the justices, the issue may resurface in some form in a future case.

\section{APPELLATE SENTENCE REVIEW UNDER RULE 7(B)}

For many years, substantive appellate sentence review under Appellate Rule 7(B) was a one-way street, with the supreme court reducing a few sentences on transfer each year. ${ }^{131}$ That rule, which implements the Indiana Constitution's power to review and revise sentences, allows appellate courts to revise a statutorily authorized sentence "if, after due consideration of the trial court's decision, the court finds that the sentence is inappropriate in light of the nature of the offense and the character of the offender." ${ }^{32}$ As summarized in recent surveys, the Indiana Supreme Court took a different course in 2012 in issuing opinions reinstating the trial court's sentence after vacating the court of appealsordered reductions; the court also became considerably less likely to grant transfer to reduce a sentence. ${ }^{133}$

\section{A. Sentences Reduced}

During the survey period, the justices reduced just one sentence, in a case

129. Horton v. State, 51 N.E.3d 1154, 1160 (Ind. 2016).

130. Rehearing orders are not published but may be accessed through the court's online docket. Appellate Case Search, COURTS.IN.Gov, https://publicaccess.courts.in.gov/docket [https://perma.cc/BZ3T-6M53] (last visited Mar. 28, 2018).

131. See Joel M. Schumm, Recent Developments in Indiana Criminal Law and Procedure, 46 IND. L. REV. 1033, 1057-62 (2013).

132. IND. R. APP. P. 7(B).

133. Schumm, supra note 131 , at 1058-59. 
involving a defendant suffering from mental illness, while reinstating the trial court's sentence after a reduction ordered by the court of appeals in another case. ${ }^{134}$ The court of appeals reduced a net of six sentences during the survey period. ${ }^{135}$ Although the supreme court statistics repeat those of last year, the number of reductions by the court of appeals doubled from the three reductions last year. ${ }^{136}$

1. Indiana Supreme Court.- In short per curiam opinions during the survey period, the Indiana Supreme Court reduced one sentence and reversed the court of appeals' reduction in another. ${ }^{137}$

First, in Wampler v. State, ${ }^{138}$ the court reduced a sentence based on a defendant's long-standing mental illness. ${ }^{139}$ There, a defendant with a long history of psychiatric hospitalizations was sentenced to thirty-three years in prison after being convicted of burglary and adjudicated a habitual offender. ${ }^{140}$ Obsessed with a former schoolmate, the defendant had entered his home where he watched him sleep, took a beer, and left a note. ${ }^{141}$

Under Appellate Rule 7(B), the supreme court reduced the sentence to sixteen years, based in part on the "strength of Judge Mathias's dissent," which it quoted at length:

The real tragedy is that Wampler was not tried under the closest alternatives we have to humane treatment of the mentally ill: as insane at the time of the behavior charged or as someone who was guilty but mentally ill. Had Wampler been found not guilty by reason of insanity, temporary or permanent commitment proceedings would have been commenced immediately for the treatment Wampler needs, and he might never emerge from the mental health system. Had he been found guilty but mentally ill, at least Wampler would have qualified for mandatory evaluation and treatment in such manner as is psychiatrically indicated for the defendant's mental illness. If found guilty but mentally ill, that treatment could also have been carried out by transfer to a state mental health facility. ${ }^{142}$

But, in Whiteside v. State, ${ }^{143}$ the Indiana Supreme Court reinstated a trial court's sixty-year sentence (maximum terms of twenty years, served

134. See generally Wampler v. State, 67 N.E.3d 633 (Ind. 2017); Whiteside v. State, 76 N.E.3d 844 (Ind. 2017).

135. See infra Part VII.A.2.

136. Joel M. Schumm, Recent Developments in Indiana Criminal Law and Procedure, 50 IND. L. REV. 1241, 1259 (2017).

137. See generally Wampler, 67 N.E.3d 633; Whiteside, 76 N.E.3d 844.

138. See generally Wampler, 67 N.E.3d 633.

139. Id. at 635 .

140. Id. at 634 .

141. Id.

142. Id. at 634-35 (internal citations and quotation marks omitted).

143. 76 N.E.3d 844 (Ind. 2017). 
consecutively on three counts) for rape and criminal deviate conduct. ${ }^{144}$ Without specific discussion of disagreement with the court of appeals' reduction to thirty years, the per curiam opinion briefly recited the facts of the case before concluding with its customary language of the legal standards and its "collective judgment" that the sentence did not warrant revision. ${ }^{145}$

Although a third case involved an underlying sentencing challenge, the grant of transfer and per curiam opinion in Karp v. State ${ }^{146}$ was solely to note the threejustice majority did not share the court of appeals' assessment of the defendant's sentencing argument, which had been described as "specious and not supported by cogent reasoning." 147 Vacating just the small portion of the court of appeals' opinion, the twenty-four-year sentence was affirmed. ${ }^{148}$

Unlike the reductions of the Shepard-led court, which often reduced sentences in cases involving lengthy sentences imposed in child sex crimes cases,${ }^{149}$ the current justices have shown little inclination to reduce sentences in cases with child victims ${ }^{150}$ —instead limiting reductions largely to cases involving young defendants, drug-related crimes, and cases like Wampler involving defendants with serious mental illness. ${ }^{151}$

2. Court of Appeals.-As explained in recent survey articles, the Indiana Supreme Court's decreased receptiveness to reducing sentences has been greeted by a similar trend in the court of appeals. ${ }^{152}$ Instead of reducing several sentences each year (twenty-six in one survey period, sixteen in another) at the beginning of this decade, one or two reductions has become more common in recent years. ${ }^{153}$ This survey period, a net of six sentences were reduced, ${ }^{154}$ which is just

144. Id. at 846 .

145. Id.

146. 61 N.E.3d 271 (Ind. 2016).

147. Id. at 271 .

148. Id.

149. Joel M. Schumm, Recent Developments in Indiana Criminal Law and Procedure, 42 IND. L. REV. 937, 949 (2009).

150. The unlikelihood of a reduction is highlighted by cases such as McCain v. State, 88 N.E.3d 1066, 1067 (Ind. 2018), which was decided after this survey period but reinstated a trial court's sentence after a reduction by the court of appeals during the survey period. There, a twentythree-year old defendant with no criminal history who had pleaded guilty was sentenced to forty years for a single incident in which she "placed her mouth on her one-year-old son's penis while bathing him." Id. at 1066-67.

151. Wampler v. State, 67 N.E.3d 633 (Ind. 2017); Schumm, supra note 131, at 1047-61.

152. Schumm, supra note 136, at 1259.

153. Id.

154. As discussed above, the court of appeals reduced the sentence in Whiteside, but that reduction was vacated by the Indiana Supreme Court and therefore is excluded from the "net" count here. See supra notes 144-46 and accompanying text (discussing Whiteside). The court of appeals' reduction in McCain was also vacated by the supreme court, as explained in footnote 151, and will be discussed in next year's survey. 
over two percent of the 272 requests from criminal defendants. ${ }^{155}$

Two of those reductions were in published opinions. First, in McFall $v$. State,${ }^{156}$ the court of appeals reduced a forty-year sentence for Class A felony manufacturing/dealing methamphetamine to thirty years (with fourteen of those years executed). ${ }^{157}$ The nature of the offense appeared to cut against a reduction; the defendant manufactured meth "in a drug house in which a housemate's children also lived." ${ }^{58}$ Rather, the opinion relied heavily on the character of the offender, noting the offense was the first felony conviction for the twenty-sevenyear-old defendant, who had made "positive changes in her life since she has been incarcerated." 159

Applying Eckelbarger v. State, ${ }^{160}$ which was discussed in last year's survey and held that consecutive sentences were inappropriate for drug convictions arising from two controlled buys and a subsequent search of the defendant's home ${ }^{161}$ in Walton v. State ${ }^{162}$ the court of appeals found that "controlled buys resulted in five dealing convictions, and the subsequent search resulted in additional drug-related convictions." 163 "Because th[o]se additional drug-related convictions [we]re supported by evidence seized as a direct result of the controlled buys," the court remanded to the trial court to impose a sentence of forty-two years: thirty-four years for the longest of the drug dealing counts (with the shorter drug-related sentences to run concurrently) and eight years on each of the non-drug-related gun convictions. ${ }^{164}$

Judge Bailey dissented on a number of issues, although he agreed with the majority that the drug-related counts must run concurrently. ${ }^{165}$ "However, given that doing so generates a conflict with the statutory sentencing limit and effects

155. The most recent year's data came from a Westlaw search of Indiana Court of Appeals' cases and is on file with the author. The author thanks Josh Woodward, IU-McKinney Class of 2017 , for his invaluable research assistance. The total number of sentencing appeals and successful challenges split fairly evenly between appeals after trial (three of 122 successful) and after guilty pleas (three of 152 successful). The supreme court upheld the enforceability of plea provisions that waive a right to challenge a sentence on appeal in Creech v. State, 887 N.E.2d 73 (Ind. 2008). Although those provisions are now standard in many counties, they appear to be never or rarely used in other counties or before certain judges.

156. 71 N.E.3d 383 (Ind. Ct. App. 2017).

157. Id. at 390-91.

158. Id. at 390. In a footnote, the court noted the offense was elevated to a Class A felony because it occurred within 1,000 feet of a youth-program center, which is "no longer an enhancing circumstance" under the current statute. Id. at 390 n.4 (citing IND. CODE § 35-48-1-16.5 (2016)).

159. Id. at 391.

160. 51 N.E.3d 169 (Ind. 2016).

161. Id. at $170-71$.

162. 81 N.E.3d 679 (Ind. Ct. App. 2017).

163. Id. at 683-84.

164. Id. "(Walton acknowledges that his gun possession is distinguishable from his drug crimes and is not subject to the Beno/Eckelbarger principle)." Id. at 684.

165. Id. at 684 (Bailey, J., dissenting). 
a notable change to the aggregate sentence length selected by the trial court, [he] would defer to the judgment of the trial court and remand for resentencing."166

Sentences were also reduced in four memorandum (unpublished) decisions. In Martin v. State, ${ }^{167}$ the court of appeals reduced a sentence for child molesting involving a female defendant with a "full-scale IQ of sixty-two" who had repeatedly molested a boy in her mother's daycare while he was six to ten years old. ${ }^{168}$ The court drew analogies to several similar cases that had reduced sentences for child molesting, beginning by acknowledging the defendant's "position of trust over B.H. and the fact that repeated incidents occurred over several years are egregious circumstances."169 Nevertheless, "B.H. was the only victim and the alleged incidents all were similar"; "there was no evidence [the defendant] used force or threats against B.H. and no evidence of physical injury to him." 170 As to her character, the defendant lacked a criminal history and had documented mental limitations. ${ }^{171}$ The court ordered the consecutive terms of forty years for each count be served concurrently, reducing the eighty-year sentence to forty. ${ }^{172}$ Judge Baker wrote separately, noting, "The majority ha[d] eloquently explained why the eighty-year sentence is inappropriate" but opined that "no more than the advisory sentence of thirty years" was appropriate in light of the defendant's mental limitations and lack of criminal history. ${ }^{173}$

In Longfellow v. State, ${ }^{174}$ the court of appeals reduced a maximum sentence of ten years for child molesting as a Level 4 felony to the advisory term of six years. ${ }^{175}$ Acknowledging the impact of the defendant's "choice to touch the breast of his granddaughter" on the victim and her family, the court nevertheless concluded, "[T] he nature of this offense is no more than what the Indiana General Assembly already took into consideration when it decided on the elements of the crime." ${ }^{176}$ As to his character, the court noted the defendant had no criminal history, took responsibility for his actions by pleading guilty, and was "eightytwo years old with significant medical issues, including a history of four heart attacks, a stroke, shortness of breath, high cholesterol, high blood pressure, memory loss, and heart problems." 177

166. $I d$. at 688 .

167. No. 20A05-1605-CR-1016, 2017 WL 2990182 (Ind. Ct. App. July 14, 2017) (unpublished disposition).

168. Id. at $* 1-2, * 5$.

169. Id. at $* 5$.

170. Id.

171. $I d$.

172. Id.

173. Id. at *5 (Baker, J., concurring and dissenting).

174. No. 34A02-1704-CR-817, 2017 WL 3758431 (Ind. Ct. App. Aug. 31, 2017) (unpublished disposition).

175. Id. at *2-3.

176. Id.

177. Id. at $* 3$. 
In Kohne v. State, ${ }^{178}$ the defendant appealed his sentence of twelve years with two of the years suspended for two counts of drunk driving causing death. ${ }^{179}$ As to the offense, the court of appeals noted the "dire consequences of his conduct, and the tragic effect the accident had on the [victims'] family, including their young daughter," who lost both of her parents in the accident. ${ }^{180}$ Nevertheless, the defendant's "conduct is what the elements of the crime already take into consideration: the reckless choice of driving under the influence and causing the death of an individual." 181 As to character, the defendant was

sixty years old with significant medical issues, including congenital heart failure, at the time of the sentencing hearing; he has been consistently employed for most, if not all, of his adult life; he has a clean criminal record; he accepted full responsibility for his actions; he showed remorse by apologizing to the [victims'] family and sought their forgiveness; and the pre-sentence investigation report indicates he is unlikely to reoffend. ${ }^{182}$

The sentence was reduced to an "aggregate sentence of eight years in the [Indiana Department of Correction (DOC)], with two years suspended to probation." 183

Finally, in Weathers v. State, ${ }^{184}$ a man "snuck a razor blade into jail during the booking process because he wanted to harm himself" and attempted suicide in his holding cell later that day. ${ }^{185} \mathrm{He}$ pleaded guilty to Level 4 felony possession of a deadly weapon while incarcerated and was sentenced to the maximum term of twelve years. ${ }^{186}$ The defendant grounded his challenge solely in the nature of the offense. ${ }^{187}$ Because his goal was to harm himself (and not another prisoner or staff), the court of appeals ordered the sentence reduced to ten years. ${ }^{188}$

\section{B. Possibility of an Increase}

The power to review and revise sentences is not limited to reducing a sentence. The Indiana Court of Appeals increased a sentence for the first time on appeal in 2010 in Akard v. State, ${ }^{189}$ where the ninety-three-year sentence was

178. No. 01A02-1608-CR-1973, 2017 WL 1381364 (Ind. Ct. App. Apr. 18, 2017) (unpublished disposition).

179. Id. at $* 1$.

180. Id. at $* 1-2$.

181. Id. at $* 2$.

182. Id.

183. Id.

184. No. 63A01-1703-CR-683, 2017 WL 3710881 (Ind. Ct. App. Aug. 29, 2017) (unpublished disposition).

185. Id. at $* 1$.

186. Id.

187. Id. at $* 2$.

188. Id.

189. 924 N.E.2d 202 (Ind. Ct. App.), aff'd in part, vacated in part, 937 N.E.2d 811, 814 (Ind. 
raised to 118 based on the horrendous nature of the crime. ${ }^{190}$ Akard relied on the supreme court's opinion in McCullough v. State, ${ }^{191}$ which made clear the power to review and revise sentences including the ability to increase a sentence on appeal — but only when the defendant requested a sentence reduction. ${ }^{192}$ Just a few weeks after granting transfer and hearing oral argument in Akard, the supreme court unanimously vacated the increased sentence, emphasizing that the prosecutor had requested a ninety-three-year sentence in the trial court and the Attorney General had argued that sentence was appropriate on appeal. ${ }^{193}$ The opinion was a narrow one that largely begged the question of when an increased sentence will be appropriate. ${ }^{194}$ Although no majority opinion since Akard has increased a sentence on appeal, again in this year's survey period two court of appeals judges wrote separate opinions to express their willingness to do so in a particular case. ${ }^{195}$

1. State's Cross-Appeal Fails, but One Judge Would Have Increased Sentence.-Facing a range of two to eight years for Class C felony child molesting, the defendant in Holt v. State ${ }^{196}$ was sentenced to four years. ${ }^{197}$ The plea agreement required concurrent sentences on the two counts and provided the State would not make a sentencing recommendation. ${ }^{198}$ The defendant requested a reduction on appeal, and the State cross-appealed to request an increase to six years for each conviction. ${ }^{199}$ The court of appeals concluded four years was not inappropriate to warrant either an increase or reduction. ${ }^{200}$ As regards the increase, the court relied on the supreme court's opinion in $A k a r d,{ }^{201}$ where the State "had requested a sentence 'no greater' than [ninety-three] years at sentencing" and asserted on appeal that the sentence of ninety-three years was

2010).

190. Id. at $210-12$.

191. 900 N.E.2d 745 (Ind. 2009).

192. Akard, 924 N.E.2d at 211 (citing McCullough, 900 N.E.2d at 750-51).

193. See Akard, 937 N.E.2d at 814 ("[W]e decline to increase the sentence here, particularly in the context of the State's request for no greater sentence at trial and its assertion on appeal that such is an appropriate sentence"). As explained in the 2011 survey, the Attorney General requested increased sentences several times in the months after McCullough was issued. Joel M. Schumm, Recent Developments in Indiana Criminal Law and Procedure, 44 IND. L. REV. 1135, 1156 (2011). That practice severely curtailed in the months and years following the supreme court's opinion in Akard.

194. Schumm, supra note 136, at 1262.

195. During last year's survey period, two court of appeals judges expressed a similar willingness. See id. at 1262-63.

196. 62 N.E.3d 462 (Ind. Ct. App. 2016).

197. Id. at 465.

198. Id. at 464.

199. Id.

200. Id. at 465-66.

201. See supra notes $190-96$ and accompanying text. 
appropriate. ${ }^{202}$ The court in Holt found Akard analogous because the State "agreed not to make a sentencing recommendation at sentencing, thereby implicitly indicating that it would agree with the trial court's sentencing determination." 203

Judge Bradford dissented and would have increased the sentence to eight years. ${ }^{204}$ The defendant had been facing "a possible sentence of one hundred and sixteen years for his most recent crimes against two young children" and had "a history of delinquent behavior" of other sex crimes against children. ${ }^{205}$

2. Middle-School Teacher's Sentence for Child Molesting Affirmed.-Facing a possible thirty-six years for three Level 4 felony counts of child molesting, a middle school teacher who molested a student was sentenced to twenty-seven years with six of those suspended to probation in Murray v. State. ${ }^{206}$ In rejecting a challenge to the appropriateness of the sentence, the court of appeals noted that the defendant had "aggressively groomed a twelve-year-old child over the course of a school year, pursuing her not only at school but also at church." ${ }^{207} \mathrm{He}$ also exploited knowledge that she was "having emotional problems . . . to further lodge himself in her life." ${ }^{208}$ Moreover, the defendant "repeatedly and aggressively violated [a] no contact order" with the victim, calling her more than fifty times, "even at a time when he knew she was suicidal." 209

Judge Crone concurred in the result, observing that he would have been inclined to increase the sentence if the State had asked for a harsher sentence based on the defendant's "egregious betrayals of his positions of trust with [the victim], his dozens of depraved phone calls to his emotionally vulnerable victim in violation of a no-contact order, and his utter lack of remorse or acceptance of responsibility."210

Thus, although McCullough makes clear the State does not need to crossappeal, ${ }^{211}$ Judge Crone's concurring opinion in Murray might encourage the State to do so in the future. And, if the State does cross-appeal, at least some judges on the court of appeals may be inclined to increase the sentence even greater than the request, as with Judge Bradford's dissent in Holt. ${ }^{212}$

\section{Death \& Life Without Parole Sentences}

Although sentencing is usually the sole function of trial judges, the jury plays

\footnotetext{
202. Holt, 62 N.E.3d at 465 (quoting Akard v. State, 937 N.E.2d 811, 814 (Ind. 2010)),

203. Id.

204. Id. at 466-67 (Bradford, J., dissenting).

205. Id. at 467 (Bradford, J., dissenting).

206. 74 N.E.3d 242, 243-44, 245 (Ind. Ct. App. 2017).

207. $I d$. at 246 .

208. Id.

209. Id.

210. Id. (Crone, J., concurring).

211. See supra notes $192-93$ and accompanying text.

212. See supra notes 205-06 and accompanying text.
} 
a determinative role when the State seeks a sentence of death or life without parole. ${ }^{213}$ Two cases, directly appealed to the Indiana Supreme Court because they involve such sentences, ${ }^{214}$ are discussed below.

In Shoun v. State, ${ }^{215}$ the supreme court found the trial court did not commit fundamental error by failing to find sua sponte that the defendant had an intellectual disability, barring a life without parole sentence, when his trial counsel withdrew the petition to determine whether he had such a disability. ${ }^{216}$ The opinion further found the sentence was neither unconstitutionally disproportionate under Article 1, Section 16 of the Indiana Constitution or inappropriate under Indiana Appellate Rule 7(B). ${ }^{217}$ The defendant had stabbed the victim countless times, while she was still alive, "from inside her body," and "some of her organs were severed and removed." 18

In Lewis v. State, ${ }^{219}$ the defendant was charged with murder and other offenses, for which the State sought a sentence of life without parole. ${ }^{220}$ Although the jury was unable to reach a unanimous verdict about the State's proof of its charged aggravating circumstance, the trial court nevertheless imposed a life imprisonment without parole sentence. ${ }^{221}$ The defendant argued and the State agreed that the "life sentence violated the Sixth Amendment because the sole aggravating factor supporting the sentence was not determined by the trier of fact beyond a reasonable doubt during the penalty phase."222 Because the State conceded it would no longer seek a life sentence and because the defendant was "already [forty-three] years of age," the supreme court "in the interests of judicial economy exercise[d its] appellate prerogative to resentence him to a term of years." 223

\section{Appellate Sentence Review Looks to All Offenses Within a Plea Agreement}

In Moyer v. State, ${ }^{224}$ the defendant pleaded guilty under "a single plea

213. IND. CODE $§ 35-50-2-9$ (e) (2017) ("If the jury reaches a sentencing recommendation, the court shall sentence the defendant accordingly.”).

214. InD. R. ApP. P. 4(A)(1). Appellate Rule 4 gives the court mandatory and exclusive jurisdiction over death penalty and life without parole (LWOP) cases. Id. But Article VII, Section 4 of the Indiana Constitution simply requires the Indiana Supreme Court to hear appeals involving a "sentence of death" - not LWOP cases. IND. ConsT. art. 7, § 4.

215. 67 N.E.3d 635 (Ind. 2017).

216. Id. at 637 .

217. Id. at $641-42$.

218. Id. at 641 .

219. 59 N.E.3d 967 (Ind. 2016).

220. Id. at 968 .

221. Id.

222. Id.

223. Id. at $968-69$.

224. 83 N.E.3d 136 (Ind. Ct. App. 2017), trans. denied, Moyer v. State, No. 79A04-1703-CR477, 2017 WL 6027740 (Ind. Nov. 30, 2017). 
agreement that covered three separate causes against him." ${ }^{225}$ The plea agreement included all three cause numbers and specified what would occur in each case and conviction, including dismissal of one entire case and several counts under another. ${ }^{226}$

Although he sought appellate review of his sentence on the remaining counts for which he was sentenced, the court of appeals emphasized the importance of the big picture. ${ }^{227}$ Failing to consider all three causes "would essentially amount to ignoring important aspects of the contract between the parties, such as the substantial benefit that he received in exchange for his guilty plea." 228 Relying on Webb v. State, ${ }^{229}$ which held that a defendant may not limit appellate review of a sentence "by merely challenging an individual sentence within a single order that includes multiple sentences," the court of appeals concluded that Moyer's "plea agreement represented a single transaction that "embodie[d] the entire agreement between the parties." ${ }^{230}$ The opinion also noted its consistency with the oft-cited principles from Cardwell v. State, ${ }^{231}$ namely that "appellate review should focus on the forest - the aggregate sentence-rather than the trees - consecutive or concurrent, number of counts, or length of the sentence on any individual count." 232

\section{OTHER SENTENCING CLAIMS}

Outside the realm of reducing sentences under Appellate Rule 7(B), the supreme and appellate court addressed other sentencing challenges.

\section{A. Confusion about Sentencing Range Requires Resentencing}

In McGuire v. State, ${ }^{233}$ the defendant "pleaded guilty to one count of Class A felony child molesting. During the plea hearing and at sentencing, the State, defense counsel, and the trial court expressed agreement that the statutory sentencing range for McGuire's crime was thirty to fifty years." 234 Sentenced to forty years, McGuire argued on appeal that the trial court's sentence was grounded in "a mistaken understanding of the minimum sentence." 235 Indeed, the statutory range for sentencing was twenty to fifty years, with an advisory term of thirty years. ${ }^{236}$ The court of appeals affirmed the sentence in a memorandum

225. Id. at 140 .

226. Id.

227. See id. (considering all three causes).

228. Id.

229. 941 N.E.2d 1082 (Ind. Ct. App. 2011).

230. Moyer, 83 N.E.3d at 140 (quoting Webb, 941 N.E.2d at 1087-88).

231. 895 N.E.2d 1219 (Ind. 2008).

232. Id. at 1225 .

233. 77 N.E.3d 1198 (Ind. 2017).

234. Id. at 1199 .

235. Id.

236. $I d$. 
decision. ${ }^{237}$ Although not entirely clear from the record, it believed the parties were confused by a statute that permitted the trial court to suspend any portion of the sentence exceeding thirty years. ${ }^{238}$ Despite the erroneous understanding of the trial court, the court of appeals affirmed because it believed the trial court would have imposed the same sentence if it had properly considered the facts and law. ${ }^{239}$

In a short per curiam opinion, the Indiana Supreme Court disagreed. ${ }^{240}$ That the statute regarding suspension of the sentence allowed the trial court to suspend a portion of McGuire's sentence "did not change the minimum sentence from twenty to thirty years. ${ }^{241}$ Relying on the somewhat analogous case from $2011,{ }^{242}$ a per curiam opinion that ordered remand based on a misunderstanding of the statutory penalties at sentencing, ${ }^{243}$ the court in McGuire ordered remand for resentencing. ${ }^{244}$ Justice Massa dissented, believing the court of appeals' decision was correct, and he thus could not "join in ordering an unnecessary remand."245

\section{B. Defendant's Youth Not a Mitigating Factor}

The court of appeals found no abuse of discretion when the trial court failed to find a defendant's youthful age of twenty as a mitigating factor in Sanders $v$. State. ${ }^{246}$ The opinion reiterated that "youth is not automatically a significant mitigating circumstance"; the issue is "within the trial court's discretion." 247 As in an earlier case, "the trial court did not overlook the defendant's youth but specifically acknowledged it and chose not to find it as a mitigating circumstance." ${ }^{248}$ That said, there are seemingly limits to a trial court's discretion; a trial court cannot refuse to find a mitigator when "the mitigating evidence is both significant and clearly supported by the record." 249

237. Id.

238. Id. (citing IND. CoDE $§ 35-50-2-2$ (i) (repealed 2014)).

239. Id.

240. Id.

241. Id.

242. Id. (citing Miller v. State, 943 N.E.2d 348, 349 (Ind. 2011)).

243. Miller, 943 N.E.2d at 349.

244. McGuire, 77 N.E.3d at 1199.

245. Id. at 1200 (Massa, J., dissenting).

246. 71 N.E.3d 839, 842-43 (Ind. Ct. App. 2017), trans. denied, 88 N.E.3d 1076 (Ind. 2017).

247. Id. at 843 (quoting and citing Smith v. State, 872 N.E.2d 169, 178 (Ind. Ct. App. 2007)).

248. Id.

249. Dowdell v. State, 720 N.E.2d 1146, 1154 (Ind. 1999). In addition, some youthful defendants may also secure a sentence reduction under Appellate Rule 7(B). See, e.g., Brown v. State, 10 N.E.3d 1, 5, 7 (Ind. 2014) (determining sentence appropriateness under Appellate Rule 7(B) and stating that "this [c]ourt has not been hesitant to reduce maximum sentences for juveniles convicted of murder."). 


\section{Defendant Entitled to Pretrial Credit on Concurrent Sentence}

In Maciaszek v. State, ${ }^{250}$ a defendant with unrelated charges in other states sought credit time toward burglary charges to which he pleaded guilty in Indiana. ${ }^{251}$ The court of appeals reiterated:

If a person incarcerated awaiting trial on more than one charge is sentenced to concurrent terms for the separate crimes, he or she is entitled to receive credit time applied against each separate term.

However, if the defendant receives consecutive terms, he or she is only allowed credit time against the total or aggregate of the terms. ${ }^{252}$

Although he was not entitled to credit time for days served in other states on unrelated charges, the defendant was entitled to the time spent in an Indiana jail awaiting trial on the Indiana charges. ${ }^{253}$ Because neither the plea agreement nor the sentencing order stated the Indiana sentence was consecutive to the New Hampshire sentence, the sentences were presumed to be concurrent, which entitled him to credit time. ${ }^{254}$

\section{Trial Courts Must Inquire Directly of Defendant about Allocution ${ }^{255}$}

Jones $v$. State, ${ }^{256}$ addresses the statutory and decisional law regarding allocution at sentencing. The statutes, long tradition of allocution rights, and "low demand upon judicial resources" compels trial courts to "inquire personally with the defendant" about allocution. ${ }^{257}$ Asking counsel instead of the defendant was fundamental error because "allocution is not an evidentiary matter or otherwise subject to proof of prejudice upon offer of proof or appeal." ${ }^{258}$ The court ordered remand for a new sentencing hearing. ${ }^{259}$ Judge Vaidik dissented, distinguishing precedent holding a personal waiver of jury trial is required and noting the Indiana Supreme Court previously held "the right to be personally addressed about the right of allocution

250. 75 N.E.3d 1089 (Ind. Ct. App.), trans. denied, 88 N.E.3d 1079 (Ind. 2017).

251. Id. at 1090-91.

252. Id. at 1092 (quoting Payne v. State, 838 N.E.2d 503, 510 (Ind. Ct. App. 2005), trans. denied).

253. Id. at 1094-95.

254. Id. at 1094. The case was also remanded for the trial court to determine his credit class. The court of appeals was unable to determine whether the defendant should receive good time credit because the record did not include his credit class. Id. at 1095 .

255. The court of appeals decided another allocution case with the same name during the survey period. Specifically, during hearings regarding a violation of community corrections the trial court should permit defendants an opportunity to "make an allocution statement when she request[s] to speak.” Jones v. State, 71 N.E.3d 412, 419 (Ind. Ct. App. 2017).

256. Jones v. State, 79 N.E.3d 911, 913 (Ind. Ct. App. 2017).

257. Id. at 916-17.

258. Id. at 917 .

259. Id. 
can be waived." ${ }^{260}$

\section{E. Trial Court's “Curt” Behavior at Sentencing Requires Reversal}

In Owens $v$. State, ${ }^{261}$ the trial court found a defendant guilty of carrying a handgun without a license and proceeded to sentencing without allowing the defendant to make a statement or defense counsel to make a legal argument. ${ }^{262}$ The court of appeals expressed its dismay with the trial court's disregard of the statute that requires asking "the defendant whether the defendant wishes to make such a statement." 263 Observing the trial court's approach was "penny wise and pound foolish," the court of appeals ordered a new sentencing hearing to rectify the "denial of due process [that] only leads us back to where defense counsel wanted us to be during sentencing, but at the expense of our taxpayers."264

\section{RESTITUTION}

Although restitution issues arose in several appellate cases, the principles explained in the following three- one from the supreme court and the other two from the court of appeals - are of particular note.

\section{A. Restitution Order Affirmed for Damage to Vehicle in Auto Theft Case}

In Archer v. State, ${ }^{265}$ the Indiana Supreme Court decided three issues related to restitution. First, the court found the defendant did not waive her right to appeal a restitution order by signing a plea agreement that included a provision waiving the right to appeal "any sentence imposed by the [trial court]." ${ }^{266}$ The agreement left blank the amount of restitution and did not provide "any mechanism for determining the amount of restitution." ${ }^{267}$ A requirement that the defendant pay restitution does not make "the amount of the restitution . . . a term of the agreement." 268

Next, by pleading guilty to auto theft, the defendant was responsible for the damage done to the vehicle while it was in her custody and control, namely a fresh coat of spray paint. ${ }^{269}$ Because the defendant agreed to pay restitution and the only damage was the spray painting, she necessarily agreed to pay for the spray-paint damage. ${ }^{270}$

260. Id. at 918 (citing Angleton v. State, 714 N.E.2d 156, 159 (Ind. 1999)).

261. 69 N.E.3d 531, 532 (Ind. Ct. App. 2017).

262. $I d$.

263. Id. at 534 (quoting IND. CoDE $\S 35-38-1-5$ (2017)).

264. Id. at 534-35.

265. 81 N.E.3d 212 (Ind. 2017).

266. Id. at 215-16.

267. Id. at 216 .

268. Id. (emphasis in original).

269. Id. at 217.

270. Id. 
Finally, the court found no abuse of discretion in ordering the defendant to pay \$25 per month, which could take years but would not result in her incarceration as long as she made a good faith effort to pay. ${ }^{271}$ Distinguishing Bell v. State ${ }^{272}$ the court emphasized that Archer agreed to pay restitution, rather than being ordered to do so after trial, and evidence showed she "is able to work and hopes to secure employment in the future," unlike the disabled defendant in Bell. ${ }^{273}$

\section{B. Restitution "as a Result of the Crime"}

The restitution statute authorizes courts to compensate crime victims for a variety of costs incurred "as a result of the crime."274 Building on Archer, the court of appeals in Postiglione v. State ${ }^{275}$ affirmed a restitution order for medical bills for a broken leg and ankle against a defendant who had started a fracas in a bar. ${ }^{276}$

The statute and decisional law do not require the injury be directly or solely "caused" by the defendant; they simply require "the victim's injury or loss be a 'result of' the defendant's crime.",277 Thus, although her co-defendants were more directly involved in inflicting the injuries, their "actions were not a separate, intervening action which might have removed [her] responsibility for restitution.".278

\section{Value of Property at Time of Loss}

Finally, in Baker v. State, ${ }^{279}$ the court of appeals reiterated that the appropriate replacement cost in ordering restitution is "the value of the destroyed item at the time of the loss." 280 There, the defendant pleaded guilty to drunk driving, which had caused an accident that totaled another vehicle. The other driver was in her father's 1996 Buick Park Avenue, for which insurance paid her father \$1,718.81; as a replacement for her father's car, the woman purchased a 2002 Buick Century for $\$ 3,800.00{ }^{281}$ The trial court ordered the defendant to pay $\$ 2,082.00$, the difference in value as restitution to cover her out-of-pocket expense. ${ }^{282}$

The court of appeals reversed, holding the other driver was entitled to "the

271. Id. at 218 .

272. 59 N.E.3d 959 (Ind. 2016).

273. Archer, 81 N.E.3d at 218.

274. IND. CODE $§ 35-50-5-3$ (a) (2017).

275. 84 N.E.3d 659 (Ind. Ct. App. 2017), trans. denied, No. 49A04-1607-CR-1662, 2017 WL 6619006 (Ind. Dec. 17, 2017).

276. Id. at 664 .

277. Id. at 665 .

278. Id. at 666 (quoting the trial court's order).

279. 70 N.E.3d 388, 391 (Ind. Ct. App.), trans. denied, 86 N.E.3d 171 (Ind. 2017).

280. Id.

281. Id. at 390 .

282. Id. 
value of the Park Avenue at the time of the accident." ${ }^{\text {283 }}$ The State's only evidence of its value was the $\$ 1,718.81$ amount paid by insurance. ${ }^{284}$ Although this amount "may or may not represent the actual replacement cost of the destroyed item," the defendant was "not entitled to a credit for the victim's insurance payment." 285 The case was remanded for the trial court to "enter a restitution order for the value of the Park Avenue prior to the accident." $" 286$

\section{Challenges to Probation CONDITIONS AND PRoBAtion ReVocation OR COMMUNITY CORRECTIONS}

Defendants frequently challenge probation conditions imposed by trial court or various aspects of the trial court's revocation of probation or community corrections. Four are included below.

\section{A. Trial Court, Not Probation, Must Impose Fees}

A trial court has discretion to impose certain probation fees against a defendant. ${ }^{287}$ If the probation department later wants to change these fees imposed by the trial court, it must petition the trial court and demonstrate a change in the financial ability of the probationer. ${ }^{288}$

In Burnett v. State, ${ }^{289}$ the court of appeals reiterated that trial courts, not the probation department, have the discretion to impose probation fees. ${ }^{290}$ There, the trial court stated the defendant had "various probation fees that are required" and its sentencing order and order of probation stated that the defendant had to follow "all standard conditions and fees of probation." 291 Because the trial court did not impose any probation fees, "it was erroneous to accept the imposition of these fees without a petition from the probation department and a showing that Burnett's financial situation has changed since the sentencing hearing." ${ }^{292}$

\section{B. Conditions Must be Related to Treatment and Public Safety}

After a defendant in Waters v. State ${ }^{293}$ was convicted of multiple counts related to the sexual assault of an adult woman, the trial court imposed four probation conditions explicitly restricting his contact with minors. ${ }^{294}$ Because

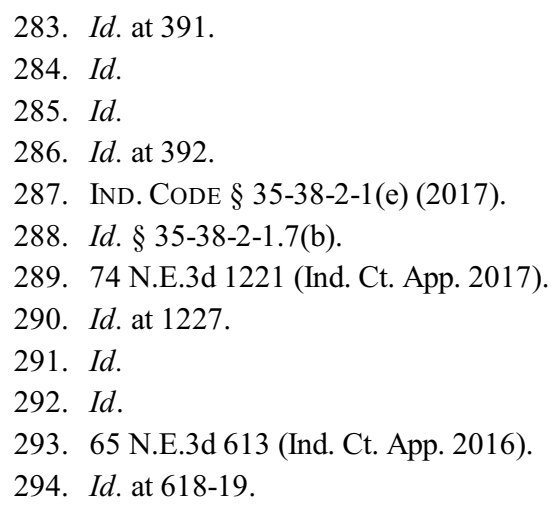


nothing in the record showed that Waters was a threat to minors, the court of appeals held these conditions were not reasonably related to his treatment or to the protection of the public. ${ }^{295}$

Another condition restricted the defendant's access to the Internet. ${ }^{296}$ But "[t]he $[\mathrm{I}]$ nternet has become increasingly pervasive in our daily lives," and the defendant had no history of illegal Internet use and did not use it as part of his crime. ${ }^{297}$ Therefore, the court of appeals held that any Internet-related condition regarding must be tailored to prevent him from using specific websites or categories of websites - and may not completely prevent his use of the internet. ${ }^{298}$

\section{Strict Liability Probation Agreement Not Enforceable}

A decade ago, the Indiana Supreme Court wrote in Woods v. State ${ }^{299}$ that "the very notion that violation of a probationary term will result in revocation no matter the reason is constitutionally suspect." ${ }^{" 300}$ Although "telling a defendant that he is on 'strict compliance' is a dramatic way of putting him on notice that he is on a short leash and has been given one final chance to 'get his act together," the supreme court limited "strict compliance" because "due process requires that a defendant be given the opportunity to explain why even this final chance is deserving of further consideration." ${ }^{301}$

Building on Woods, during this survey period the court of appeals found error with another form of strict compliance or zero tolerance arrangement. ${ }^{302} \mathrm{In}$ Hampton v. State ${ }^{303}$ the defendant stipulated that she had violated the conditions of her probation and agreed to a sanction of 550 days in the DOC, and with that commitment stayed for six months. ${ }^{304}$ The agreement provided, if at the time of the review hearing, she had completed all terms the sentence would be withdrawn, but if she had not completed all terms and obligations her sentence would be executed. ${ }^{305}$ "The parties further agreed that, 'The Court has no authority to alter this [A]greement without the consent of the State and defendant." "306 The evidence at the review hearing showed the defendant had not called in to probation as required and failed to make the required payments. ${ }^{307}$

295. Id. at 619 .

296. Id.

297. Id. at 619-20.

298. Id.

299. 892 N.E.2d 637 (Ind. 2008).

300. Id. at 641 .

301. Id.

302. See Hampton v. State, 71 N.E.3d 1165 (Ind. Ct. App.), trans. denied, 88 N.E.3d 1077 (Ind. 2017).

303. Id. at 1167.

304. Id.

305. Id.

306. Id.

307. Id. at 1168 . 
"Noting that it lacked the authority to change the Agreement, the trial court ordered Hampton to serve 550 days in the DOC, less credit time."’308

The court of appeals reversed and remanded to the trial court "for it to determine the appropriate sanction to impose for Hampton's violations of its order." ${ }^{309}$ Quoting Woods, the court rejected the analogy between a strict compliance probation agreement and a plea agreement: "A defendant who enters a plea agreement knowingly, intelligently, and voluntarily is hardly similarly situated to a defendant who is advised in essence either agree to strict compliance or go to jail now for violating probation." ${ }^{\text {1 } 10}$

\section{Lengthy Prison Sentence Excessive for Community Corrections Violation}

In Johnson v. State, ${ }^{311}$ the trial court appropriately found the defendant violated the term of his community corrections (home detention) placement that he not leave his apartment when he was sitting outside on a bench..$^{312}$ Nevertheless, the decision to order him to serve the seven-year sentence in prison was reversed in light of "the level of Johnson's functioning and his resources, his previous successful placement on work release, the nature of the violation, and the severity of the court's sentence." ${ }^{\prime 13}$ Rather, citing the handful of cases where the court of appeals had previously found a trial court abused its discretion in imposing a penalty when revoking probation or community corrections, the court of appeals remanded to the trial court with instructions to order the remaining sentence be served on work release." ${ }^{314}$

\section{CONCLUSION}

With only two months on the Indiana Supreme Court bench for Justice Goff and less than sixteen for Justice Slaughter when the survey period ended in September 2017, it is early to attempt to predict trends among the new Indiana Supreme Court. A state supreme court has considerable influence not only through those opinions it agrees to hear on discretionary review but also the more than ninety percent of cases it lets stand. ${ }^{315}$ Courts can issue broad, far-reaching opinions or decide issues narrowly. As recounted above, the justices issued reasonably broad and far-reaching opinions on issues such as video evidence in Love and restitution in Archer this year and Bell last year. Although the Shinnock case on corpus delicti involved an unusual set of facts, the opinion was written

\footnotetext{
308. Id.

309. Id. at 1174 .

310. Id. (quoting Woods v. State, 892 N.E.2d 637, 640 n.2 (Ind. 2008)).

311. 62 N.E.3d 1224 (Ind. Ct. App. 2016).

312. Id. at 1231 .

313. Id.

314. Id. at 1232 .

315. See Indiana Supreme Court AnNuAl RePORT 14 (2016-2017), available at $\mathrm{http} / / / w w w . i n . g o v / j u d i c i a r y / s u p r e m e / f i l e s / 1617$ report.pdf [perma.cc/N6GB-ACC4] (noting that of 484 criminal cases before the court, thirty-four opinions (seven percent) were issued).
} 
in a manner that applies more broadly when the issue arises in future cases. ${ }^{316}$ Many opinions, however, resolved issues quite narrowly, and the court has increasingly turned to per curiam opinions that provide little reasoning - essentially declaring that the court of appeals was correct or incorrect with little explanation of reasons that may be applied in future cases.

Nearly a quarter of the criminal appellate docket was decided in the court's eight per curiam opinions. Five of these were discussed above, specifically, three sentencing cases (Whiteside, Wampler, and McGuire) and the Miller case on remedies for erroneous legal statements at bench trials. ${ }^{317}$ In the fifth and most narrow, three justices granted transfer simply to vacate part of a court of appeals' opinion that had characterized an argument as "specious and not supported by cogent reasoning." 318 Although not shaping a major legal doctrine for decades, that opinion surely sent a clear message to the court of appeals about the manner and tone in which to address arguments of counsel.

The three additional per curiam opinions not discussed above were similarly narrow. First, in Middleton v. State ${ }^{319}$ the court granted transfer to reiterate the correct standard in reviewing a claim of ineffective assistance of counsel. Demonstrating prejudice from counsel's deficient performance requires a petitioner to show "a reasonable probability that, but for counsel's unprofessional errors, the result of the proceedings would have been different." ${ }^{320}$ Next, in McNeal v. State, ${ }^{321}$ the court "vacate[d] a portion of the court of appeals' opinion discussing the community caretaking exception to the Fourth Amendment's warrant requirement." 322 This led to the same result because the defendant's "encounter with police was justified by reasonable suspicion of public intoxication." 323 Finally, a per curiam rehearing opinion addressed a claim of factual inaccuracy in an earlier per curiam opinion on sentencing. The court acknowledged the defendant in a child solicitation case was "correct that the record reflects he solicited his niece to sit on his lap and she declined, not that he "had her sit on his lap," as the opinion stated. ${ }^{324}$ Nevertheless, the court otherwise affirmed the original opinion that upheld the trial court's sentence because the "factual difference [did] not alter our original decision." ${ }^{325}$ Other examples in

316. Admittedly, some of the far-reaching opinions in criminal cases involve evidentiary or Indiana constitutional law issues that are discussed elsewhere in this survey issue.

317. See generally Whiteside v. State, 76 N.E.3d 844 (Ind. 2017); Wampler v. State, 67 N.E.3d 633 (Ind. 2017); McGuire v. State, 77 N.E.3d 1198 (Ind. 2017); Miller v. State, 77 N.E.3d 1196 (Ind. 2017).

318. See supra notes $147-49$ and accompanying text.

319. 72 N.E.3d 891 (Ind. 2017).

320. Id. at 891 (quoting Strickland v. Washington, 466 U.S. 668, 694 (1984)) (emphasis in Middleton).

321. 76 N.E.3d 136 (Ind. 2017).

322. Id. at 137 .

323. Id.

324. Bess v. State, 65 N.E.3d 593, 594 (Ind. 2016).

325. Id. 
recent years include adoption of a well-reasoned majority or dissenting court of appeals' opinion. ${ }^{326}$

Vacating an unnecessary or problematic part of a court of appeals opinion - or adopting part or all of an opinion - is easily and appropriately done in a short per curiam opinion. Use of per curiam opinions in sentencing cases often signals to litigants and lower courts that something was the wrong answer without providing much insight on the right answer. Some of the ambiguity is inherent in the nature of the claim; as the supreme court wrote a decade ago, "[t]he principal role of appellate review should be to attempt to leaven the outliers, and identify some guiding principles for trial courts and those charged with improvement of the sentencing statutes, but not to achieve a perceived 'correct' result in each case." ${ }^{327}$

In contrast to most per curiam opinions, the Miller opinion addressed a significant issue of broad applicability, creating new law on an issue of first impression rather than applying well-settled law to a common scenario. The per curiam Miller opinion took a position opposite the court of appeals' thorough, unanimous opinion. ${ }^{328}$ But the supreme court's analysis, after recounting the State's contention in a sentence, was limited to a single sentence, without citation to legal authority. ${ }^{329}$

The Indiana Appellate Rules offer criteria for the court of appeals to consider in deciding whether to issue a published/precedential opinion or a memorandum, non-citable decision. ${ }^{330}$ No analogous rule addresses criteria for issuing per curiam opinions. A treatise on appellate practice suggests a "full opinion" be issued in any one of the following circumstances:

(a) In deciding the appeal the court enunciates a new rule of law or modifies an existing rule.

(b) In deciding the appeal the court resolves a conflict or apparent conflict of authority between its own panels or between subordinate courts.

(c) The court is not unanimous in the disposition.

(d) The decision is of substantial public interest. ${ }^{331}$

326. See, e.g., McKeen v. Turner, 71 N.E.3d 833, 834 (Ind. 2017) (“"grant[ing] transfer and adopt[ing] and incorporat[ing] by reference the Court of Appeals opinion"); Weaver v. State, 56 N.E.3d 25, 26 (Ind. 2016) (agreeing with the dissenting opinion that the evidence was sufficient to support a conviction for refusal to identify).

327. Cardwell v. State, 895 N.E.2d 1219, 1225 (Ind. 2008).

328. Miller v. State, 72 N.E.3d 502 (Ind. Ct. App.), aff'd in part, vacated in part, Miller v. State, 77 N.E.3d 1196 (Ind. 2017).

329. Miller, 77 N.E.3d at 1197 ("We agree the correct remedy in these circumstances is a remand for reconsideration by the trial court.").

330. IND. APP. R. 65(A).

331. Daniel J. Meador et al., Appellate Courts: Structures, Functions, Processes, And Personnel 508 (1994) (quoting Carrington, MeAdor, \& Rosenberg, Justice on APPeAl 31-35 (1976)). 
Most of the per curiam opinions do not fall within any of the four categories. Time will tell if that trend continues or these abbreviated opinions are used to decide issues of broader reach, like the Miller opinion, which arguably fell within categories a, c, and d. 